\title{
DETERMINANTS OF INNOVATION IN A SMALL OPEN ECONOMY: A MULTIDIMENSIONAL PERSPECTIVE
}

\author{
Luísa Carvalho ${ }^{1}$, Teresa Costa ${ }^{2}$, Jorge Caiado ${ }^{3}$ \\ ${ }^{1}$ CEFAGE, Center for Advanced Studies in Management and Economics, Évora University, \\ Palácio do Vimioso (Gab 224) Largo Marquês de Marialva 8, 7000-809, Évora, Portugal \\ ${ }^{1,2}$ School of Business Administration, ESCE/Polytechnic Institute of Setúbal, \\ Campus do IPS, Estefanilha, 2914-503 Setúbal, Portugal \\ ${ }^{2}$ CITIS, Research Centre on Tourism, Innovation and Services, Lusiada University, \\ Rua da Junqueira, 188-198, 1349-001 Lisbon, Portugal \\ ${ }^{3}$ CEMAPRE, Centre for Applied Mathematics and Economics and School of Economics and \\ Management, ISEG/Technical University of Lisbon, Rua do Quelhas 6, \\ 1200-781 Lisbon, Portugal \\ E-mails: ${ }^{1}$ luisa.carvalho@esce.ips.pt (correspondingauthor); ${ }^{2}$ teresa.costa@esce.ips.pt; \\ 3jcaiado@iseg.utl.pt
}

Received 18 September 2011; accepted 06 June 2012

\begin{abstract}
This paper uses logistic regression analysis to examine how intramural and extramural R\&D, acquisition of machinery, equipment and software, acquisition of external knowledge, training, market introduction and other procedures and technical preparations determine the innovation behaviour of manufacturing and service firms. We adopt a multidimensional view of innovation by considering product, process, organizational and marketing innovations as dependent variables separately. The study reports on the Community Innovation Survey (CIS4) of a small open-economy country. The empirical results indicate that intramural $R \& D$ has a positive impact on innovation. In contrast, the influence of extramural R\&D on innovation is unclear. All innovation activities contribute towards organizational innovation. The study also suggests that there are no significant differences between services and manufacturing firms concerning the propensity to innovation.
\end{abstract}

Keywords: innovation, manufacturing firms; service firms, CIS.

Reference to this paper should be made as follows: Carvalho, L.; Costa, T.; Caiado, J. 2013. Determinants of innovation in a small open economy: a multidimensional perspective, Journal of Business Economics and Management 14(3): 583-600.

JEL Classification: L60, L80, O30, O32.

\section{Introduction}

In the last few years, policy makers have recognized the importance of innovation in business competitiveness. For most economists, innovation is considered a driving force behind a prosperous economy (Schumpeter 1934; Solow 1957; Lundvall 1992; Nelson 
1993; Edquist 1997; Jorgensen, Stiroh 1999). Others point to innovation as the major contributor to the productivity growth and firm performance (Kemp et al. 2003).

At the Lisbon Summit in March 2000, the European Union declared its ambition to make Europe the most competitive and innovative region. According to Post-2010 Lisbon Strategy (European Commission 2008), a long-term perspective is needed to maintain and enhance European living standards considering the ageing (and shrinking) of Europe's population. The improvement of productivity depends on challenges related to new technologies and innovation.

The innovation process refers to the transformation process in an innovation trajectory (Kemp et al. 2003). According to Pianta (2005), innovation is an extremely differentiated process, specific in its scope, nature and potential impact. Different types of innovation have different outcomes insofar as economic performance, depending on the particular strategies followed by firms and industries.

Most of the studies only refer to process and product innovation (Barras 1986; Brouwer, Kleinknecht 1999; Frenz, Ietto-Gilles 2003; Pianta 2005; Utterback 1996). However, other innovation typologies become more relevant to firms. Besides products and services, innovation also includes new processes, new organizational models, new distribution channels or new marketing activities and new business concepts, which have a significant impact on productivity and growth (Schumpeter 1934, 1943; Hjalager 2002; CIS 2004; Drejer 2004; Fagerberg 2005; OECD 2005; Weiermair 2006). This paper aims to identify and analyze contributions made by the seven innovation activities of CIS4 (Community Innovation Survey), considering the four different innovation typologies: product, process, organizational and marketing in a small open economy (Portugal).

There are several studies that use some of the innovation activities of CIS4. Most of these studies have examined the relation between size, R\&D or multinationality and innovation (Castellani, Zanfei 2007; Frenz, Ietto-Giles 2003; Frenz et al. 2005; Criscuolo et al. 2010). Considering the use of CIS databases, most of these studies analyze innovation with regard to R\&D (Mohnen, Hoareaou 2002; Criscuolo, Haskel 2003; Mairesse, Mohnen 2005; Hölzl 2009; Kumi-Ampofo, Brooks 2009). However, other important innovation inputs, such as acquisition of machinery and equipment, acquisition of external knowledge, training, marketing activities and other procedures and technical preparations considered in CIS4 have rarely been explored in innovation studies. Also, some empirical studies confirm differences in innovation behavior by sector (Barras 1986; Utterback 1996; Abramovsky et al. 2004). Others studies (Pires et al. 2008) using Portuguese CIS3 conclude that there are few differences between service and manufacturing with regard to propensity to innovate. In addition, Sirilli and Evangelista (1998) find similarities between service firms and the manufacturing ones.

This finding led us to the research question: "Are all the seven innovation activities of CIS4 important to explain propensity to innovate in manufacturing and service sectors in a small open economy?"

The answer to this question may contribute to a better suitability of the CIS4 to measure firms' propensity to innovate and could provide clues to the formulation of more appropriate public policies. 
In the last years several studies used CIS databases. Frenz (2002) identified several aspects to be considered in empirical studies that uses CIS database: 1) possibility of comparison among different CIS editions; 2) use of a large number of observations; 3 ) analyse categories according with sectors; 4) analyze according with level of knowledge and technology (low, medium and high by sector); 5) possibility to compare the main variables of CIS4.

The contributions of this article are threefold. First, we apply logistic regression to investigate the impact of the seven innovation activities of CIS4 on different innovation typologies of Portuguese firms, using the Community Innovation Survey (CIS) questionnaire guided by Oslo Manual standards (OECD 1997, 2005). Second, we compare the innovation behavior of firms in manufacturing and service sectors. Third, we apply an empirical model, with results that could be useful for firms. The empirical results could provide relevant information about several innovation inputs that can support good practices of innovation management.

The outline of the article is as follows. Section 2 presents a literature review and hypotheses development. Section 3 provides data. Section 4 presents a brief description of the methodology. Section 5 reports the empirical findings. Finally, section 6 is the conclusion.

\section{Literature review and hypotheses}

The vast majority of innovation studies focus on the distinction between innovation and invention. "Invention is the first occurrence of an idea for a new product or process, while innovation is the first attempt to carry it out into practice" (Fagerberg 2005). In our perspective, innovation is a process that includes invention, commercialization and diffusion with a multidimensional and nonlinear track, which implies the sustainability of the product or service in the market. In the $60 \mathrm{~s}$ and $70 \mathrm{~s}$, some models tried to explain the innovation process. The first models considered innovation as a linear model of (science) push and (demand) pull. This perspective changed in the $80 \mathrm{~s}$ and more complex models emerged, such as the chain-linked model (Kline, Rosenberg 1986), coupling model (Rothwell, Zegveld 1985). These models explain innovation by looking at complex interactions and linkage mechanisms.

Innovation has been a topic of different studies in economics, management, technology, sociology and may have particular interpretations according to different points of view (Arrow 1962; Pavitt 1984; Cohen, Lewin 1989; Urban 2009). Economics theory received an important contribution from Joseph Schumpeter (1934), who defined economic innovation as:

- The introduction of a new good with which consumers are not yet familiar or of a new quality of a good;

- The introduction of a new method of production, which need by no means be founded upon a discovery scientifically new, and can also exist in a new way of handling a commodity commercially;

- The opening of a new market that is a market into which the particular branch of manufacture of the country in question has not previously entered, whether or not this market has existed before; 
- The conquest of a new source of supply of raw materials or half-manufactured goods, again irrespective of whether this source already exists or whether it has first to be created;

- The carrying out of the new organization of any industry, like the creation of a monopoly position (for example through trustification) or the breaking up of a monopoly position.

In order to apply the logistic model, the results of CIS4 (OECD 1997, 2005) are used considering the four innovation typologies: product (good or service) innovation, process innovation, organizational innovation, marketing innovation. Some studies suggest some relations between inputs of innovation and typologies. The most important evidences are the relation between $\mathrm{R} \& \mathrm{D}$ and product, process and marketing innovation (Cohen, Klepper 1991, 1992; Balachandra, Friar 1997; Conte, Vivarelli 2005; Unger 2005). More recently Cardomone (2010), studied the relation between R\&D and innovation and confirmed that firms' R\&D investments are positively correlated with the probability of introducing product innovations and negatively with the probability of introducing process innovations. She also confirmed that expenditure on technology acquisition (TA, including equipment, machinery, licenses and software) is positively correlated with the probability of carrying out process innovation and negatively with product innovation.

According to the European Commission (2007), in terms of the nature of innovative activities and innovation performance, there are differences between industry sectors, but there are also differences between firms belonging to the same industry category. The interplay between firm-level factors and industry sector specific conditions clearly deserves more attention in future research in the field of innovation studies. Other studies confirm these differences in innovation by sector (Barras 1986; Utterback 1996; Abramovsky et al. 2004).

Most of the studies only took into account a small number of innovation activities in order to explain the occurrence of innovation. However, the multidimensionality of this phenomenon justifies the importance of considering a set of variables called innovation activities in CIS4:

- Intramural (in-house) R\&D - creative work undertaken within the enterprise to increase the stock of knowledge and its use to devise new and improved products and processes "including software development";

- Extramural R\&D - same activities as intramural R\&D but undertaken by other companies (including other enterprises within the group) or by public or private research organizations and purchased by the enterprise;

- Acquisition of machinery and equipment - acquisition of advanced machinery, equipment and computer hardware or software to produce new or significantly improved products and processes;

- Acquisition of other external knowledge - purchase or licensing of patents or nonpatented inventions, know-how and other types of knowledge from other enterprises or organizations; 
- Training - internal or external training for staff specifically for the development and/or introduction of new significantly improved products and processes;

- Market introduction of innovations - activities for the market introduction of new or significantly improved goods or services including market research and launch advertising;

- Other procedures - procedures and technical preparations to implement new or significantly improved products and processes that are not covered elsewhere.

$\mathrm{R} \& \mathrm{D}$ is one of the most used inputs to study where innovation occurs (Cohen, Klepper 1991, 1992; Unger 2005). However, the isolated use of R\&D presents some limitations because it reflects only the resources devoted to producing innovative output and does not consider the amount of innovative activity actually achieved (Acs, Audretsch 2003). In this sense, Kleinknecht and Verspagen (1989), and Kleinknecht et al. (1991) have analytically demonstrated that R\&D measures incorporate only efforts made to improve innovative activity that are carried out within formal R\&D budgets and within formal $R \& D$ laboratories. These authors thought that informal R\&D is significant especially in small firms.

Considering other variables, Lach and Rob (1996) studied the causal relationship between R\&D, and machinery and equipment. Schmookler (1966) expressed the view that improvements in performance associated with technological progress can result either from intramural R\&D or from R\&D performed in other firms/industrial sectors and embodied in ideas or goods purchased by an industry. Papaconstantinou et al. (1996) argued that "in terms of supply and demand of technology, it establishes that while innovations are developed mainly in a cluster of high technology manufacturing industries, a different cluster of industries in the services sector are the main acquirers of technologically sophisticated machinery and equipment. R\&D performance is more concentrated (the top 5 industries account for between $60-80 \%$ of total) than technology use (the top 5 user industries account in most countries for $40-50 \%$ of total)".

The following two hypotheses are established:

H1: Intramural $R \& D$ is positively related to the firms' propensity to innovate;

H2: Extramural R\&D is positively related to the firms' propensity to innovate.

Several authors refers the importance of the expenditure on acquisition of machinery, equipment, software and external knowledge to firm's propensity to innovate (Mansfield 1988; Shieds, Yong 1994; Archibugi et al. 1995; Weiss 2003; Camacho, Rodriguez 2005; Canepa, Stoneman 2008; Elche, González 2008). This literature review permitted the formulation of $\mathrm{H} 3$ :

H3: Acquisition of machinery and equipment is positively related to the firms' propensity to innovate.

Considering training, Becker (1964) emphasized the importance of on-the-job training to productivity. He argued that firms will only invest in specific training if they can appropriate the future rent of training. Steedmann (1993) and Krueger (1993) and Autor (2001), Acemoglu and Pischke (1999) complement Becker's perspective and argued 
that noncompetitive labor markets, in combination with a compressed wage structure, can also provide an incentive for firm-sponsored general training because firms can appropriate parts of the expected rent. Also Laursen and Foss (2003) argued that training (internal and external) creates a positive impact to innovation.

According with other authors the impact of trust on knowledge acquisition and innovation research shows that trust increases knowledge acquisition from external partners; contributes to innovation and enlarge business opportunities (Tsai, Ghoshal 1998; Yli-Renko et al. 2001). The literature cited above leads to the formulation of the following hypotheses:

H4: Acquisition of other external knowledge is positively related the firms' propensity to innovate;

H5: Training is positively related to the firms' propensity to innovate.

Several authors suggest that market product introduction is influenced by some factors that can be divided into company level factors and environmental factors (Dess, Beard 1984; Dierickx, Cool 1989; Suarez 2004). The following hypothesis is established:

H6: Market introduction of innovations is positively related to the firms' propensity to innovate.

Mainly in the case of the technological innovation it is required technical preparation and procedures related with learning and utilization process (Cohen, Lenvinthal 1989; Dodgson 1993; Hit et al. 2000). Also Schiiling and Werr (2009) found that flexibility in the innovation process can be influenced by technical changes. The following hypothesis is established:

H7: Other procedures and technical preparations are positively related to the firms' propensity to innovate.

\section{Data}

Our empirical study uses the Portuguese Community Innovation Survey 4 (CIS4). This survey coverage included several sub-sectors in services as well as manufacturing, excluding firms recorded as having less than 10 employees as well as excluding non-profit services. The Community Innovation Survey provides information about structural features of the firms (which includes the nationality of the company to which the enterprise belongs and whether the enterprise is or not part of a group belonging to the same company); performance elements; innovation inputs and outputs; barriers to innovation; information sources; innovation protection, and others. Nevertheless some authors (Tether 2001; Arundel et al. 2007) point out some limitations of CIS data, such as, the study of the services sector, the difficulty in measure innovation not based on R\&D, the interpretation of many CIS questions as a consequence of innovative capabilities of the responding firms and sophistication of their markets, etc. The data includes 4,504 firms and covers innovation activities for the three years from 2002 to 2004. Of these firms, 2,010 (46.6\%) were service firms, and 2,404 (53.4\%) were manufacturing firms. 
Our aim is to investigate the determinants of innovation behaviour of manufacturing and services companies. To do this we have to choose the dependent variables and the input or independent variables to include in the regression models. Four dichotomous dependent variables are considered: product innovation, process innovation, organizational innovation and marketing innovation.

A product innovation indicates whether or not the firm introduces any new or improved products (goods or services), such as improved software, user friendliness, components or subsystems. The innovation (new or improved) must be new to the enterprise but it does not need to be new to the sector or the market. It does not matter if innovation is originally developed by the enterprise or by other enterprises (CIS4 2006).

A process innovation indicates whether or not the firm introduced any new or improved process, such as new or significant production process, distribution method or support activities for the goods or services. The innovation (new or improved) must be new to the enterprise but it does not need to be new to the sector or to the market. It does not matter if innovation is originally developed by the enterprise or by other enterprises. Exclude purely organizational innovations (CIS4 2006).

Organizational innovation indicates whether or not the firm implemented new or significant changes in the firm's structure or management methods that are intended to improve firm's use of knowledge, quality of goods or services or the efficiency of workflow.

Marketing innovation indicates whether or not the firm implemented any new or significantly improved designs on sales methods to increase the appeal of goods and services to enter in new market (CIS4 2006).

Intramural (in-house) R\&D (rrdin), extramural R\&D (rrdex), acquisition of machinery, equipment and software ( $r m a c)$, acquisition of other external knowledge (roek), training (rtr), market introduction of innovation (rmar) and other procedures and technical preparations (rpre) were used as inputs or predictors of innovation.

\section{Methodology}

Logistic regression analysis is used to investigate the effects of a number of explanatory variables on a binary response variable (a variable which can take only two values, 0/1 or no/yes). In our study, this response variable represents the presence or absence of innovation.

Let $Y_{i}$ be a response variable of interest and $X_{1 i}, X_{2 i}, \ldots, X_{p i}$ be a set of possible explanatory variables. The logistic regression model can be written as:

$$
L_{i}=\log \left(\pi_{i} /\left(1-\pi_{i}\right)\right)=\beta_{0}+\beta_{1} X_{1 i}+\cdots+\beta_{p} X_{p i},
$$

where

$$
\pi_{i}=E\left(Y_{i}=1 \mid X_{1}, \ldots, X_{p}\right)=\frac{\exp \left(\beta_{0}+\beta_{1} X_{1 i}+\cdots+\beta_{p} X_{p i}\right)}{1+\exp \left(\beta_{0}+\beta_{1} X_{1 i}+\cdots+\beta_{p} X_{p i}\right)}
$$


is the probability that the event of interest occurs; and

$$
1-\pi_{i}=E\left(Y_{i}=0 \mid X_{1}, \ldots, X_{p}\right)=\frac{1}{1+\exp \left(\beta_{0}+\beta_{1} X_{1 i}+\cdots+\beta_{p} X_{p i}\right)},
$$

is the probability that the event of interest does not occur. Therefore, $\pi_{i} /\left(1-\pi_{i}\right)$ is simply the odds ratio of the event of interest, that is, the ratio of the probability that the event occurs to the probability that it does not occur. In the model (1), $L_{i}=\log \left(\pi_{i} /\left(1-\pi_{i}\right)\right)$ is called the logit and is the natural logarithm of the odds ratio, where the range of probabilities lies between 0 and 1 . The odds ranges from 0 to $+\infty$. $L$ becomes positive as the odds ratio increases from 1 to $+\infty$ and becomes negative as the odds ratio decreases from 1 to 0 . For a more detailed discussion of logistic regression models, see, for example, Maddala (1983) and Collet (2002).

Logistic regression relies on maximum likelihood estimation rather than OLS estimation. The interpretation of the logistic model given above is as follows. The $k$ th slope coefficient, say $\beta_{k}$, indicates how the predicted values change as the corresponding independent variable changes by a unit (holding other variables constant), that is, it measures the change in the logarithmic odds of success $(Y=1)$ for a unit change in the corresponding independent variable. Since here the predicted values are the logarithms of the odds ratios, we can obtain the estimated odds ratio by computing the exponential of the corresponding slope coefficient as follows: $\hat{\pi}_{i} /\left(1-\hat{\pi}_{i}\right)=\exp \left(\hat{\beta}_{k}\right)$. Then we can subtract 1 from it and multiply the result by $100,\left(\exp \left(\hat{\beta}_{k}\right)-1\right) \times 100$, and we get the percent change in the odds for a unit increase in the $k$ th regressor.

\section{Results}

To investigate in which economic sectors innovation is more likely to occur, we obtain a two-way table of absolute and relative frequencies between economic sector and innovation, as shown in Table 1. The manufacturing companies were divided into three industry sectors: low-tech industry, medium-tech industry and high-tech industry. The services companies were divided into two sectors: trade and services, and transport and telecommunications.

For overall data set, the shares of product innovation, process innovation, organizational innovation and marketing innovation were about 26.8\%, 23.8\%, 36.1\% and 18.3\%, respectively. The odds of product innovation are $1207 / 3297=0.37$, which means that there are 0.37 companies where product innovation occurred for one company where product innovation did not occur. The odds of process innovation, organizational innovation and marketing innovation are $0.31,0.56$ and 0.22 , respectively. Medium and high-tech industrial companies have higher odds of innovation than low-tech industrial companies. Trade and services companies and transport and telecommunications companies have lower odds of product innovation and process innovation than high-tech industrial companies, but higher odds of organizational innovation. The odds of presence of innovation are lower than the odds of absence of innovation for all economic sub-sectors. 
Table 1. Two-way table of absolute and relative frequencies

\begin{tabular}{lcccccccc}
\hline \multirow{2}{*}{ Sector } & \multicolumn{2}{c}{$\begin{array}{c}\text { Product } \\
\text { innovation }\end{array}$} & \multicolumn{2}{c}{$\begin{array}{c}\text { Process } \\
\text { innovation }\end{array}$} & \multicolumn{2}{c}{$\begin{array}{c}\text { Organizational } \\
\text { innovation }\end{array}$} & \multicolumn{2}{c}{$\begin{array}{c}\text { Marketing } \\
\text { innovation }\end{array}$} \\
\cline { 2 - 10 } & No & Yes & No & Yes & No & Yes & No & Yes \\
\hline \multirow{2}{*}{ Low-tech industry } & 1067 & 287 & 1026 & 328 & 1030 & 324 & 1142 & 212 \\
& 78.80 & 21.20 & 75.78 & 24.22 & 76.07 & 23.93 & 84.34 & 15.66 \\
\hline \multirow{2}{*}{ Medium-tech } & 383 & 234 & 392 & 225 & 396 & 221 & 490 & 127 \\
industry & 62.07 & 37.93 & 63.53 & 36.47 & 64.18 & 35.82 & 79.42 & 20.58 \\
\hline \multirow{2}{*}{ High-tech industry } & 268 & 164 & 299 & 133 & 283 & 149 & 348 & 84 \\
& 62.04 & 37.96 & 69.21 & 30.79 & 65.51 & 34.49 & 80.56 & 19.44 \\
\hline \multirow{2}{*}{ Industry } & 1718 & 685 & 1717 & 686 & 1709 & 694 & 1980 & 423 \\
& 71.49 & 28.51 & 71.45 & 28.55 & 71.12 & 28.88 & 82.40 & 17.60 \\
\hline \multirow{2}{*}{ Trade and Services } & 1421 & 469 & 1543 & 347 & 1039 & 851 & 1520 & 370 \\
& 75.19 & 24.81 & 81.64 & 18.36 & 54.97 & 45.03 & 80.42 & 19.58 \\
\hline Transport and & 158 & 53 & 174 & 37 & 132 & 79 & 180 & 31 \\
telecommunications & 74.88 & 25.12 & 82.46 & 17.54 & 62.56 & 37.44 & 85.31 & 14.69 \\
\hline \multirow{2}{*}{ Services } & 1579 & 522 & 1717 & 384 & 1171 & 930 & 1700 & 401 \\
& 75.15 & 24.85 & 81.72 & 18.28 & 55.74 & 44.26 & 80.91 & 19.09 \\
\hline \multirow{2}{*}{ Total } & 3297 & 1207 & 3434 & 1070 & 2880 & 1624 & 3680 & 824 \\
& 73.20 & 26.80 & 76.24 & 23.76 & 63.94 & 36.06 & 81.71 & 18.29 \\
\hline
\end{tabular}

Table 2 shows the results of the logistic regressions for product innovation, process innovation, organizational innovation and marketing innovation for the whole data and for the data of separated manufacturing and services firms. Table 3 gives the correct classification rate of presence of innovation (sensitivity), the correct classification rate of absence of innovation (specificity) and the overall correct classification rate (CCR).

For product innovation and process innovation regressions, rrdin, rmac, rtr and rpre are statistically significant at the 5\% level and have odds ratio greater than 1 for both manufacturing and services firms. This suggests that companies which engaged in intramural R\&D, acquisition of machinery, equipment and software, training, and other preparations are more likely to innovate than companies that did not engage in it.

There are several studies using CIS databases that relate innovation to R\&D (Mohnen 2002; Mairesse, Mohnen 2005; Hölzl 2009; Kumi-Ampofo, Brooks 2009). However, it was not possible to identify studies that confirm a positive relation between innovation types and other variables considered in CIS (acquisition of machinery and equipment, training and other procedures). Arundel (2007) also concluded that the majority of scholarly researches on innovation focus almost exclusively on R\&D, disregarding other methods that firms use to innovate.

The odds ratios of market introduction of innovations (rmar) suggest a positive impact on product innovation but a negative impact on process innovation. In the organizational and marketing innovation regressions, the odds ratio of activities for the market introduction of innovations is also significant at the conventional levels. Several stud- 
ies indicate the market-driven businesses create products that transform market needs (Jaworski, Kohli 1993; Narven, Slater 1990). The market-orientated behaviour yields superior innovation and greater new product success (Deshpandé, Webster 1993; Kohli, Jaworski 1990). Other studies confirm the results achieved concluding that businesses with a strong market orientation are best situated for new product success no matter the business environment (Slater, Narver 1994).

Table 2. Logistic regression analysis

\begin{tabular}{|c|c|c|c|c|c|}
\hline Data & Variable & $\begin{array}{l}\text { Product } \\
\text { innovation }\end{array}$ & $\begin{array}{l}\text { Process } \\
\text { innovation }\end{array}$ & $\begin{array}{c}\text { Organizational } \\
\text { innovation }\end{array}$ & $\begin{array}{l}\text { Marketing } \\
\text { innovation }\end{array}$ \\
\hline \multirow{11}{*}{ All firms } & rrdin & $3.256^{*}$ & $2.421 *$ & $1.781 *$ & $1.514 *$ \\
\hline & rrdex & 0.815 & 0.984 & $1.449 *$ & 1.000 \\
\hline & rmac & $4.795 *$ & $15.750 *$ & $1.518^{*}$ & $1.430 *$ \\
\hline & roek & $1.284 * * *$ & 1.203 & $1.753^{*}$ & $1.606^{*}$ \\
\hline & $r t r$ & $2.469 *$ & $1.788^{*}$ & $1.771^{*}$ & 0.984 \\
\hline & rmar & $2.948^{*}$ & $0.769 * *$ & $1.641^{*}$ & $4.100 *$ \\
\hline & rpre & $2.102 *$ & $2.488^{*}$ & $1.448^{*}$ & $1.661^{*}$ \\
\hline & $\mathrm{N}$ & 4500 & 4500 & 4500 & 4500 \\
\hline & $\log \mathrm{L}$ & -1478.35 & -1412.10 & -2452.97 & -1764.10 \\
\hline & $\mathrm{LR} \mathrm{Chi}^{2}$ & $2274.63^{*}$ & $2105.35^{*}$ & $979.41 *$ & $756.50 *$ \\
\hline & Pseudo $\mathrm{R}^{2}$ & 0.435 & 0.427 & 0.166 & 0.177 \\
\hline \multirow{11}{*}{ Manufacturing } & rrdin & $3.102 *$ & $2.026^{*}$ & $1.876^{*}$ & $1.612 *$ \\
\hline & rrdex & 0.924 & 0.850 & $1.505 * *$ & 0.794 \\
\hline & rmac & $6.147^{*}$ & $29.847 *$ & $1.834^{*}$ & $1.968^{*}$ \\
\hline & roek & 1.227 & 0.971 & $1.970^{*}$ & $1.858^{*}$ \\
\hline & $r t r$ & $2.841 *$ & $2.306^{*}$ & $2.026^{*}$ & 1.114 \\
\hline & rmar & $3.582 *$ & 0.807 & $1.340 * *$ & $4.534 *$ \\
\hline & rpre & $2.243 *$ & $2.299 *$ & $1.504^{*}$ & $1.542 *$ \\
\hline & $\mathrm{N}$ & 2401 & 2401 & 2401 & 2401 \\
\hline & $\log \mathrm{L}$ & -745.33 & -706.46 & -1144.85 & -871.26 \\
\hline & $\mathrm{LR} \mathrm{Chi}^{2}$ & $1378.56^{*}$ & $1456.70 *$ & $597.72 *$ & $493.63 *$ \\
\hline & Pseudo $\mathrm{R}^{2}$ & 0.481 & 0.508 & 0.207 & 0.221 \\
\hline \multirow{11}{*}{ Services } & rrdin & $3.162 *$ & $2.948^{*}$ & $1.872 *$ & $1.404 * *$ \\
\hline & rrdex & 0.795 & 1.245 & $1.329 * * *$ & 1.268 \\
\hline & rmac & $3.162 *$ & $4.146^{*}$ & $1.530^{*}$ & 1.010 \\
\hline & roek & $1.370 * * *$ & $1.568^{*}$ & $1.605^{*}$ & $1.408 * * *$ \\
\hline & $r t r$ & $2.794 *$ & $3.360^{*}$ & $1.296^{*}$ & 0.898 \\
\hline & rmar & $2.796^{*}$ & 0.785 & $1.999^{*}$ & $3.841^{*}$ \\
\hline & rpre & $1.958^{*}$ & $3.017^{*}$ & $1.413 * *$ & $1.804 *$ \\
\hline & $\mathrm{N}$ & 2099 & 2099 & 2099 & 2099 \\
\hline & $\log \mathrm{L}$ & -704.12 & -599.41 & -1241.83 & -879.21 \\
\hline & LR Chi ${ }^{2}$ & 946.38 & 795.71 & 398.90 & 289.09 \\
\hline & Pseudo $\mathrm{R}^{2}$ & 0.402 & 0.399 & 0.138 & 0.141 \\
\hline
\end{tabular}

Note: Predictor variable effects are reported as odds ratios; $\mathrm{LR} \mathrm{Chi}^{2}$ is the likelihood-ratio chi-squared test; The McFadden (1973) Pseudo $\mathrm{R}^{2}$ is computed as $1-\log \left(\mathrm{L}_{\mathrm{f}}\right) / \log \left(\mathrm{L}_{\mathrm{i}}\right)$, where $\log \left(\mathrm{L}_{\mathrm{i}}\right)$ is the initial iteration's $\log$-likelihood and $\log \left(\mathrm{L}_{\mathrm{f}}\right)$ is the final iteration's $\log$-likelihood.

$*, * *$ and $* * *$ indicates significant at $1 \%, 5 \%$ and $10 \%$ level, respectively. 
Table 3. Performance evaluation measures

\begin{tabular}{llcccc}
\hline \multicolumn{1}{c}{ Data } & Criteria & $\begin{array}{c}\text { Product } \\
\text { innovation }\end{array}$ & $\begin{array}{c}\text { Process } \\
\text { innovation }\end{array}$ & $\begin{array}{c}\text { Organizational } \\
\text { innovation }\end{array}$ & $\begin{array}{c}\text { Marketing } \\
\text { innovation }\end{array}$ \\
\hline All firms & Sensitivity & $69.27 \%$ & $67.67 \%$ & $52.59 \%$ & $32.89 \%$ \\
& Specificity & $89.50 \%$ & $89.34 \%$ & $87.13 \%$ & $95.16 \%$ \\
& CCR & $84.07 \%$ & $84.20 \%$ & $74.67 \%$ & $83.76 \%$ \\
\hline \multirow{2}{*}{ Manufacturing } & Sensitivity & $65.57 \%$ & $80.41 \%$ & $51.87 \%$ & $37.83 \%$ \\
& Specificity & $92.02 \%$ & $89.23 \%$ & $89.46 \%$ & $94.34 \%$ \\
& CCR & $85.34 \%$ & $86.71 \%$ & $78.59 \%$ & $84.38 \%$ \\
\hline \multirow{2}{*}{ Services } & Sensitivity & $62.64 \%$ & $51.44 \%$ & $55.48 \%$ & $22.94 \%$ \\
& Specificity & $89.92 \%$ & $94.00 \%$ & $82.21 \%$ & $96.47 \%$ \\
& CCR & $83.13 \%$ & $86.23 \%$ & $70.37 \%$ & $82.42 \%$ \\
\hline
\end{tabular}

Note: Sensitivity is the percentage of observations with predicted probability greater than or equal to 0.5 given that innovation occurred $(Y=1)$; Specificity is the percentage of observations with predicted probability lower than 0.5 given that innovation did not occur $(Y=0)$; CCR is the overall correct classification rate.

The acquisition of other external knowledge (roek) has a positive significant effect on innovation (both product and process) in service firms but not in manufacturing firms. In the product, process and marketing innovation regressions, the odds ratio of extramural R\&D is not statistically significant at the $10 \%$ level. Some studies point out that organization cannot rely exclusively on internal sourcing but also require knowledge from beyond their boundaries when developing their innovations (Rigby, Zook 2002). Additionally, other studies confirm that as well as doing own research and development, firms typically use knowledge sources external to the firm through licensing, contracting out R\&D, acquiring other firms, or attracting qualified researchers embodying relevant knowledge (Arora, Gambardella 1994; Cockburn, Henderson 1998; Granstrand et al. 1992). However, some empirical studies have found evidence of the effects of external knowledge-sourcing strategies on the development of both product and process innovations (Vega-Jurado et al. 2009). This conclusion could justify the differences between services and manufacturing firms.

The statistical significance and magnitude of the odds ratios for organizational innovation regressions are also very encouraging. All variables have significant and positive effects on organizational innovation for both manufacturing and service firms. Pierce and Delbecq (1977) refer that the conceptualization of organizational innovation suggests that innovation within an organization is a complex multiphased activity moving from initiation to adoption and implementation. This approach considers organizational innovation as a sum of several inputs inside the organization. Additionally, Cohen and Levinthal (1990) confirm that outside sources of knowledge are often critical to the innovation process, in any organizational level at which the innovating unit is defined. The results suggest that organizational innovation requires transversal inputs and assumes relevance in both sectors (services and manufacturing).

Intramural R\&D, other external knowledge acquisition, marketing activities and other procedures and technical preparations contribute positively to marketing innovation. 
Extramural R\&D and training effects appear to be unimportant in marketing innovation, while acquisition of machinery, equipment and software is significant in manufacturing firms but not in services firms.

Best sensitivity $(80.41 \%)$ is obtained for the process innovation model for manufacturing firms. The marketing innovation model for services firms has the best specificity (96.47\%). The overall correct classification rate is over $83 \%$ for product innovation, process innovation and marketing innovation models for the whole data, while the correct classification for organizational innovation is about $75 \%$. However, the differences between manufacturing and services firms turn out to be not statistically different.

\section{Conclusions}

This study is an examination into a multidimensional view of innovation with respect to product, process, organizational and marketing innovation. Logistic regression modeling was used to evaluate the effect of intramural (in-house) R\&D, extramural R\&D, acquisition of machinery, equipment and software, acquisition of other external knowledge, training, market introduction of innovation and other procedures and technical preparations to increase the odds of innovation.

The results indicate that intramural $\mathrm{R} \& \mathrm{D}$ has a positive impact on innovation, as suggested by others studies. In contrast, the influence of extramural R\&D on product, process and marketing innovations is not statistically significant. Our interpretation of this finding is that companies perhaps prefer to invest in intramural R\&D because it is easy to protect and appropriate of the knowledge, and the innovation management process (from idea to innovation outcome) is controlled by the company. Consequently, this kind of R\&D allows for knowledge internalization and core business focus. Apart from this, intramural R\&D investment is probably related with the motivation to achieve high efficiency, particularly through cost reductions in the long term, mainly in the case of large firms that have R\&D departments. Our results also show that the acquisition of machinery and equipment, the acquisition of other external knowledge and other procedures and technical preparations have a substantial influence on all types of innovations. Some of these innovation inputs may be related with access to new technologies and intangible resources that firms can outsource (when a firm lacks the right competencies). In addition, the results strongly confirm that all the innovation predictors are important to organizational innovation. This finding supports the multidimensional perspective of innovation typology.

Regarding our research question: "Are all the seven innovation activities of CIS4 important to explain propensity to innovate in manufacturing and service sectors?", we have reached the conclusion that all the seven innovation activities of CIS4 are relevant to explain propensity to innovate, despite the few situations were innovation activities do not contribute to firms' propensity to innovate (see Table 4). Additionally, the results reveal small differences between manufacturing and service innovation. This corroborates others studies that show that services and innovation in services is essentially similar to 
Table 4. Summary of hypothesis testing

\begin{tabular}{|c|c|c|c|c|c|}
\hline & \multirow{2}{*}{ Hypothesis } & \multicolumn{4}{|c|}{ Decision (accept/reject) } \\
\hline & & Product & Process & Organization & Marketing \\
\hline H1 & $\begin{array}{l}\text { Intramural R\&D is positively related } \\
\text { to the firms' propensity to innovate }\end{array}$ & $\begin{array}{l}\text { Accept } \\
(\mathrm{M} / \mathrm{S})\end{array}$ & $\begin{array}{l}\text { Accept } \\
(\mathrm{M} / \mathrm{S})\end{array}$ & $\begin{array}{l}\text { Accept } \\
(\mathrm{M} / \mathrm{S})\end{array}$ & $\begin{array}{l}\text { Accept } \\
(\mathrm{M} / \mathrm{S})\end{array}$ \\
\hline $\mathbf{H} 2$ & $\begin{array}{l}\text { Extramural R\&D is positively related } \\
\text { to the firms' propensity to innovate }\end{array}$ & Reject & Reject & $\begin{array}{l}\text { Accept } \\
(\mathrm{M} / \mathrm{S})\end{array}$ & Reject \\
\hline H3 & $\begin{array}{l}\text { Acquisition of machinery and } \\
\text { equipment is positively to the firms' } \\
\text { propensity to innovate }\end{array}$ & $\begin{array}{l}\text { Accept } \\
(\mathrm{M} / \mathrm{S})\end{array}$ & $\begin{array}{l}\text { Accept } \\
(\mathrm{M} / \mathrm{S})\end{array}$ & $\begin{array}{l}\text { Accept } \\
(\mathrm{M} / \mathrm{S})\end{array}$ & $\begin{array}{l}\text { Accept } \\
\text { (M) }\end{array}$ \\
\hline H4 & $\begin{array}{l}\text { Acquisition of other external } \\
\text { knowledge is positively related to the } \\
\text { firms' propensity to innovate }\end{array}$ & $\begin{array}{l}\text { Accept } \\
\text { (S) }\end{array}$ & $\begin{array}{l}\text { Accept } \\
\text { (S) }\end{array}$ & $\begin{array}{l}\text { Accept } \\
(\mathrm{M} / \mathrm{S})\end{array}$ & $\begin{array}{l}\text { Accept } \\
(\mathrm{M} / \mathrm{S})\end{array}$ \\
\hline H5 & $\begin{array}{l}\text { Training is positively related to the } \\
\text { firms' propensity to innovate }\end{array}$ & $\begin{array}{l}\text { Accept } \\
(\mathrm{M} / \mathrm{S})\end{array}$ & $\begin{array}{l}\text { Accept } \\
(\mathrm{M} / \mathrm{S})\end{array}$ & $\begin{array}{l}\text { Accept } \\
(\mathrm{M} / \mathrm{S})\end{array}$ & Reject \\
\hline H6 & $\begin{array}{l}\text { Marketing introduction of innovations } \\
\text { is positively related to the firms' } \\
\text { propensity to innovate }\end{array}$ & $\begin{array}{l}\text { Accept } \\
(\mathrm{M} / \mathrm{S})\end{array}$ & Reject & $\begin{array}{l}\text { Accept } \\
(\mathrm{M} / \mathrm{S})\end{array}$ & $\begin{array}{l}\text { Accept } \\
(\mathrm{M} / \mathrm{S})\end{array}$ \\
\hline H7 & $\begin{array}{l}\text { Other procedures and technical } \\
\text { preparations is positively related to the } \\
\text { firms' propensity to innovate }\end{array}$ & $\begin{array}{l}\text { Accept } \\
(\mathrm{M} / \mathrm{S})\end{array}$ & $\begin{array}{c}\text { Accept } \\
(\mathrm{M} / \mathrm{S})\end{array}$ & $\begin{array}{l}\text { Accept } \\
(\mathrm{M} / \mathrm{S})\end{array}$ & $\begin{array}{l}\text { Accept } \\
(\mathrm{M} / \mathrm{S})\end{array}$ \\
\hline
\end{tabular}

Note: ' $M$ ' denotes manufacturing services and ' $S$ ' services firms.

manufacturing and innovation in manufacturing. These results suggest that differences in innovation management between service and manufacturing become less important, in part because of the hybridization of products and services.

Finally, this empirical study presents new research work that uses the seven innovation activities of CIS4 to explain firms' propensity to innovate and confirms the suitability of these indicators in a small open economy.

However, some limitations of this study can be identified. Firstly, the input variables selected from CIS data could not cover all relevant types of input innovation, particularly in the case of the services sector. Secondly, there's a difficulty in generalizing the findings as applied to the Portuguese economy with relation to others economies with different economic features. In conclusion, it would be interesting to widen the scope of this study to include other European economies where the manufacturing sector is more relevant, and verify possible differences or similarities.

\section{References}

Abramovsky, L.; Harrison, R.; Simpson, H. 2004. Increasing innovative activity in the UK? Where now for government support for innovation and technology transfer, IFS Briefing Note No. 53. Institute for Fiscal Studies: London, UK.

Acemoglu, D.; Pischke, J. 1999. Beyond Becker: training in imperfect labour markets, Economic Journal 109: 12-142. http://dx.doi.org/10.1111/1468-0297.00405 
Acs, Z. J.; Audretsch, D. B. 2003. Innovation and technological change, in Z. J. Acs, D. B. Audretsch (Eds.). Handbook of Entrepreneurship Research: An Interdisciplinary Survey and Introduction. Dordrecht: Kluwer Academic Publishers, 55-79.

Archibugi, D.; Evangelista, R.; Simonetti, R. 1995. Concentration, firm size and innovation: evidence from innovation costs, Technovation 15(3): 153-164.

http://dx.doi.org/10.1016/0166-4972(95)96616-2

Arora, A.; Gambardella, A. 1994. Evaluating technological information and utilizing it: scientific knowledge, technological capability and external linkages in biotechnology, Journal of Economic Behavior and Organisation 24(1): 91-114. http://dx.doi.org/10.1016/0167-2681(94)90055-8

Arrow, K. 1962. Uncertainty and the welfare economics of medical care, The American Economic Review 53: 941-973.

Arundel, A. 2007. Innovation survey indicators: what impact on innovation policy?, in Science, Technology and Innovation Indicators in a Changing World: Responding to Policy Needs. Paris: OECD, 49-64.

Arundel, A.; Bordoy, C.; Mohnen, P.; Smith, K. H. 2007. Surveys and policy: lessons from the CIS, in C. Nauwelaers, R. Wintjes (Eds.). Innovation Policy in Europe. Cheltenham: Edward Elgar Publishing Ltd, 3-38.

Autor, D. H. 2001. Why do temporary help firms provide free general skills training?, Quarterly Journal of Economics 116: 1409-1448. http://dx.doi.org/10.1162/003355301753265615

Balachandra, R.; Friar, J. 1997. Factors for success in R\&D projects and new product innovation: a contextual framework, IEEE Transactions on Engineering Management 44(3): 276-287. http://dx.doi.org/10.1109/17.618169

Barras, R. 1986. Towards a theory of innovation in services, Research Policy 15: 161-173. http://dx.doi.org/10.1016/0048-7333(86)90012-0

Becker, G. S. 1964. Human Capital. Chicago: University of Chicago Press.

Brouwer, E.; Kleinknecht, A. 1999, Innovative output, and a firm's propensity to patent: an exploration of CIS micro data, Research Policy 28(6): 615-624.

http://dx.doi.org/10.1016/S0048-7333(99)00003-7

Camacho, A.; Rodríguez, J. M. 2005. How innovative are services? An empirical analysis for Spain, The Service Industries Journal 25(2): 253-271. http://dx.doi.org/10.1080/0264206042000305448

Canepa, A.; Stoneman, P. 2008. Financial constraints to innovation in the UK: evidence from CIS2 and CIS3, Oxford Economic Papers 60(4): 711-731. http://dx.doi.org/10.1093/oep/gpm044 Cardamone, P. 2010. The role of R\&D spillovers in product and process innovation, Applied Economics Letters 17(5): 483-493. http://dx.doi.org/10.1080/13504850801935349

Castellani, D; Zanfei, A. 2007. Multinational companies and productivity spillovers: is there a specification error?, Applied Economics Letters 14(14): 1047-1051.

http://dx.doi.org/10.1080/13504850600706503

CIS IV 2004. Quarto Inquérito Comunitário à Inovação. Ministério da Ciência, Tecnologia e Ensino Superior, EUROSTAT, Lisbon.

Cockburn, I.; Henderson, R. 1998. Absorptive capacity, coauthoring behavior and the organisation of research in drug discovery, Journal of Industrial Economics 46: 157-182.

http://dx.doi.org/10.1111/1467-6451.00067

Cohen, W. M.; Levinthal, D. A. 1990. Absorptive capacity: a new perspective on learning and innovation, Administrative Science Quarterly 35(1): 128-152. http://dx.doi.org/10.2307/2393553

Cohen, W. M.; Levinthal, F. A. 1989. Innovation and learning: the two faces of R\&D, Economic Journal 99(397): 56-59. http://dx.doi.org/10.1016/S1573-448X(89)02006-6

Cohen, W.; Klepper, S. 1991. Firm size versus diversity in achievement of technological advance, Handbook of Industrial Organization 2: 1059-1107. 
Cohen, W.; Klepper, S. 1992. The trade off between firm size and diversity in the pursuit of technological progress, Small Business Economics 4: 1-14.

Cohen, W.; Lewin, R. 1989. Empirical studies of innovation and market structures, in R. Schmlensee, R. Willig (Eds.). Handbook of Industrial Organization, 2. Elsevier Science Publishers: 1059-1107.

Conte, A.; Vivarelli, M. 2005. One or many knowledge production functions? Mapping innovative activity using microdata, IZA Discussion Paper no. 1878. Forschungsinstitut zur Zukunft der Arbeit, Institute for the Study of Labor.

Criscuolo, C.; Haskel, J. 2003. Innovations and productivity growth in the UK: evidence from CIS2 and CIS3, CeRiBA Working Paper.

Criscuolo, C.; Haskel, J.; Slaughter, M. 2010. Global engagement and the innovation activities of firms, International Journal of Industrial Organization 28(2): 191-202.

http://dx.doi.org/10.1016/j.ijindorg.2009.07.012

Deshpandé, R.; Webster, F. 1993. Cooperate culture, costumer orientation and innovativeness in Japanese firms: a quadrate analysis, Journal of Marketing 57: 23-27.

http://dx.doi.org/10.2307/1252055

Dess, G.; Beard, D. 1984. Dimensions of organizational task environments, Administrative Science Quarterly 29: 52-73. http://dx.doi.org/10.2307/2393080

Dierickx, I.; Cool, K. 1989. Asset stock accumulation and sustainability of competitive advantage, Management Science 35: 1504-1512. http://dx.doi.org/10.1287/mnsc.35.12.1504

Dodgson, M. 1993. Organizational learning: a review of some literature, Organization Studies 14(3): 375-394. http://dx.doi.org/10.1177/017084069301400303

Drejer, I. 2004. Identifying innovation surveys of services, Research Policy 33: 551-562.

http://dx.doi.org/10.1016/j.respol.2003.07.004

Edquist, C. 1997. Systems of Innovation - Technologies, Institutions and Organizations. London, UK: Pinter.

European Commission. 2007. Monitoring Industrial Research: The 2007 EU Industrial R\&D Investment Scoreboard [online], [cited 4 August 2010]. Joint Research Centre. Available from Internet: http://iri.jrc.ec.europa.eu/research/docs/2007/eur22928en.pdf

European Commission. 2008. Non Paper on the Lisbon Strategy for Growth and Jobs After 2010 [online], [4 August 2010]. Available from Internet: http://www.planotecnologico.pt/en/lisbonstrategy/the_post_2010_lisbon_strategy/list.aspx

Fagerberg, J. 2005. Innovation: a guide to the literature, in J. Fagerberg, et al. (Eds.). The Oxford Handbook of Innovation. Oxford: Oxford University Press, 1-26.

Frenz, M. 2002. A comparison of second and third UK community innovation survey, TESE Economics and Statistics Reports 6. http://dx.doi.org/10.1080/1366271042000339067

Frenz, M.; Girardone, C.; Ietto-Gillies, G. 2005. Multinationality matters in innovation, the case of the UK financial services, Industry and Innovation 12(1): 65-92.

Frenz, M.; Ietto-Gillies, G. 2003. The impact of multinationality on the propensity to innovate: an analysis of the UK community innovation survey 3, in The International Workshop, Empirical Studies in Innovation in Europe, University of Urbino, 1-2 December 2003.

Granstrand, O.; Bohlin, E.; Oskarsson, C.; Sjöberg, N. 1992. External technology acquisition in large multitechnology corporations, $R \& D$ Management 22: 111-133.

http://dx.doi.org/10.1111/j.1467-9310.1992.tb00801.x

Hitt, M. A.; Ireland, R. D.; Lee, H. 2000. Technological learning, knowledge management, firm growth and performance: an introduction essay, Journal of Engineering and Technology Management 17(3/4): 231-246. http://dx.doi.org/10.1016/S0923-4748(00)00024-2 
Hjalager, A. M. 2002. Repairing innovation defectiveness in tourism, Tourism Management 23: 465-474. http://dx.doi.org/10.1016/S0261-5177(02)00013-4

Hölzl, W. 2009. Is the R\&D behaviour of fast-growing SMEs different? Evidence from CIS III data for 16 countries, Small Business Economics 33(1): 59-75.

http://dx.doi.org/10.1007/s11187-009-9182-x

Jaworski, B. J.; Kohli, A. K. 1993. Market orientation: antecedents and consequences, Journal of Marketing 57: 53-70. http://dx.doi.org/10.2307/1251854

Jorgensen, D. W.; Stiroh, K. J. 1999. Information technology and growth, AEA Papers and Proceedings May: 109-115.

Kemp, R. G. M.; Folkeringa, M.; Jong, de J. P. J.; Wubben, E. F. M. 2003. Innovation and firm performance, Research Report 2002 07. Zoetermeer, Netherlands: EIM.

Kleinknecht, A.; Poot, T. P.; Reijnen, J. O. N. 1991. Formal and informal R\&D and firm size: survey results from the Netherlands, in Z. J. Acs, D. B. Audretsch (Eds.). Innovation and Technological Change. East Lansing, MI: The University of Michigan Press, 84-108.

http://dx.doi.org/10.1007/BF00393808

Kleinknecht, A.; Verspagen, B. 1989. R\&D and market structure: the impact of measurement and aggregation problems, Small Business Economics 1: 297-302.

Kline, S. J.; Rosenberg, N. 1986. An overview of innovation, in R. Landau, N. Rosenberg (Eds.). The Positive Sum Strategy. Washington: National Academy Press, 275-307.

Kohli, A; Jaworski, B. 1990. Market orientation: the construct research propositions and managerial implications, Journal of Marketing 54: 1-8. http://dx.doi.org/10.2307/1251866

Krueger, A. B. 1993. How computers have changed the wage structure: evidence from microdata, 1984-1989, Quarterly Journal of Economics 108(1): 33-60. http://dx.doi.org/10.2307/2118494

Kumi-Ampofo, F.; Brooks, C. 2009. Innovation among SMEs: evidence from the Yorkshire and Humber region, International Journal of Entrepreneurship and Small Business 8(4): 516-533. http://dx.doi.org/10.1504/IJESB.2009.025696

Lach, S.; Rob, R. 1996. R\&D, investment, and industry dynamics, Journal of Economics and Management Strategy 5: 217-249. http://dx.doi.org/10.1111/j.1430-9134.1996.00217.x

Laursen, K.; Foss, N. 2003. New human resource management practices, complementarities and the impact on innovation, Cambridge Journal of Economics 27: 243-263.

http://dx.doi.org/10.1093/cje/27.2.243

Lundvall, B. 1992. National Systems of Innovation: Towards a Theory of Innovation and Interactive Learning. London, UK: Pinter.

Maddala, G. S. 1983. Limited-dependent and Qualitative Variables in Economics. New York: Cambridge University Press.

Mairesse, J.; Mohnen, P. 2005. The importance of R\&D for innovation: a reassessment using French survey data, The Journal of Technology Transfer 30: 183-197.

http://dx.doi.org/10.1007/s10961-004-4365-8

Mansfield, E. 1988. The speed and cost of industrial innovation in Japan and the United States: external vs. internal technology, Management Science 34(10): 1157-1168.

http://dx.doi.org/10.1287/mnsc.34.10.1157

McFadden, D. 1973. Conditional logit analysis of qualitative choice behavior, in P. Zarembka (Ed.). Frontiers in Econometrics. New York: Academic Press, 105-142.

Mohnen, P.; Hoareau, C. 2002. What type of enterprise forges close links with universities and government labs? Evidence from CIS2, Working paper. Université du Québec à Montréal, University Maastricht: MERIT and CIRANO.

Narven, J. C.; Slater, S. 1990. The effect of market orientation on business profitability, Journal of Marketing 54: 20-35. http://dx.doi.org/10.2307/1251757 
Nelson, R. 1993. National Innovation Systems: A Comparative Analysis. Oxford: Oxford University Press.

OECD. 1997. Oslo Manual: Proposed Guidelines for Collecting and Interpreting Technological Innovation Data. Paris: OECD.

OECD. 2005. Oslo Manual: Guidelines for Collecting and Interpreting Innovation Data. Paris: OECD.

Papaconstantinou, G.; Sakurai, N.; Wyckoff, A. 1996. Embodied technology diffusion: an empirical analysis for 10 OECD countries, STI Working Papers 1996/1. Paris: OECD.

Pavitt, K. 1984. Sectoral patterns of technical change: towards a taxonomy and a theory, Research Policy 13(6): 343-373. http://dx.doi.org/10.1016/0048-7333(84)90018-0

Pianta, M. 2005. Innovation and employment, in J. Fagerberg, D. Mowery, R. Nelson (Eds.). Handbook of Innovation. Oxford University Press, Chapter 22: 568-598.

Pierce, J. L.; Delbecq, A. L. 1977. Organization structure, individual attitudes and innovation, The Academy of Management Review 2(1): 27-37.

Pires, C.; Sarkar, S.; Carvalho, L. 2008. Innovation in services - how different from manufacturing?, Service Industries Journal 28(10): 1339-1356. http://dx.doi.org/10.1080/02642060802317812

Rigby, D.; Zook, C. 2002. Open-market innovation, Harvard Business Review Oct.: 80-89.

Rothwell, R.; Zegveld, W. 1985. Reindustrialization and Technology. London: Longman.

Schiiling, A.; Werr, A. 2009. Managing and Organizing for Innovation in Service Firms. Stockholm: VINNOVA - Swedish Governmental Agency for Innovation Systems.

Schmookler, J. 1966. Invention and Economic Growth. Cambridge: Harvard University Press. $250 \mathrm{p}$.

Schumpeter, J. 1934. The Theory of Economic Development. Harvard University Press.

Schumpeter, J. 1943. Capitalism, Socialism and Democracy. New York: Harper and Row.

Shields, M.; Young, S. 1994. Managing innovation costs: a study of cost consciousness behavior by R\&D professionals, Journal of Management Accounting Research 6: 175-189.

Sirilli, G.; Evangelista, R. 1998. Technological innovation in services and manufacturing: results from Italian surveys, Research Policy 27(9): 881-899.

http://dx.doi.org/10.1016/S0048-7333(98)00084-5

Slater, S.; Narver, J. C. 1994. Does competitive environment .moderate the market orientation performance relationship?, Journal of Marketing 58(January): 56-65.

Solow, R. 1957. Technical change and the aggregate production function, Review of Economics and Statistics 39: 312-320. http://dx.doi.org/10.2307/1926047

Steedmann, H. 1993. The economics of youth training in Germany, Economic Journal 103: 1279-1291. http://dx.doi.org/10.2307/2234254

Suarez, F. F. 2004. Battles for technological dominance: an integrative framework, Research Policy 33: 271-286. http://dx.doi.org/10.1016/j.respol.2003.07.001

Tether, B. 2001. Identifying innovation, innovators and innovative behaviours: a critical assessment of the Community Innovation Survey (CIS), CRIC Discussion Paper No. 48. CRIC, University of Manchester and UMIST, Manchester, UK.

Tsai, W.; Ghoshal, S. 1998. Social capital and value creation: the role of intrafirm networks, Academy of Management Journal 41(4): 464-476. http://dx.doi.org/10.2307/257085

Unger, B. 2005. Problems of measuring innovative performance, in S. Casper, F. Van Waarden (Eds.). Innovation and Institutions - a Muldisciplinary Review of the Study of Innovation Systems. Cheltenham, UK: Edward Elgar, 19-50. 
Urban, W. 2009. Service quality gaps and their role in service enterprises development, Technological and Economic Development of Economy 15(4): 631-645.

http://dx.doi.org/10.3846/1392-8619.2009.15.631-645

Utterback, J. 1996. Mastering Dynamics of Innovation. Boston: Harvard Business School Press.

Vega-Jurado, J.; Gutierrez-Gracia, A.; Fernandez-de-Lucio, I. 2009. Does external knowledge sourcing matter for innovation? Evidence from the Spanish manufacturing industry, Industrial and Corporate Change 18(4): 637-670. http://dx.doi.org/10.1093/icc/dtp023

Weiermair, K. 2006. Product improvement or innovation: what is the key to success in tourism?, in Innovation and Growth in Tourism. Paris: OECD, 53-69.

Weiss, P. 2003. Adoption of product and process innovations in differentiated markets: the impact of competition, Review of Industrial Organization 23: 301-314.

http://dx.doi.org/10.1023/B:REIO.0000031372.79077.fc

Yli-Renko, H.; Autio, E.; Sapienza, H. J. 2001. Social capital, knowledge acquisition, and knowledge exploitation in young technology-based firms, Strategic Management Journal 22(6/7): 587-613. http://dx.doi.org/10.1002/smj.183

Luísa CARVALHO. Dr Luísa Carvalho is Adjunct Professor at the Business School, Setubal Polytechnic Institute (Portugal) and Researcher at Center for Advanced Studies in Management and Economics, University of Évora. She received her $\mathrm{PhD}$ in Management from the University of Évora (Portugal). She is the author of several articles in scientific journals, international conferences, books and book chapters. Her current research interests are in the areas of entrepreneurship, innovation, internationalization and services sector.

Teresa COSTA. Dr Teresa Costa is Adjunct Professor at the Business School, Setubal Polytechnic Institute (Portugal). She holds a PhD in Management from the Lusíada University. She is author of several articles in scientific journals, international conferences, books and book chapters. She is the author of several articles in scientific journals, international conferences, books and book chapters. Her current research interests are in the areas of innovation, entrepreneurship, strategy and sustainability.

Jorge CAIADO. Dr Jorge Caiado is Assistant Professor at the School of Business and Economics (ISEG), Technical University of Lisbon and Researcher at the Centre for Applied Mathematics and Economics, Technical University of Lisbon. He received his PhD in Mathematics Applied in Economic and Management from the School of Business and Economics, Technical University of Lisbon (Portugal). He is the author of several articles in scientific journals, international conferences, books and book chapters. His current research interests are in the areas of financial econometrics, quantitative finance, computational statistics, time series analysis, multivariate data analysis and forecasting. 